\title{
Reuse of Cement Kiln Dust for backfilling and $\mathrm{CO}_{2}$ carbonation
}

\author{
Marcin Lutyński ${ }^{1, *}$, and Piotr Pierzyna ${ }^{1}$ \\ ${ }^{1}$ Faculty of Mining and Geology, Silesian University of Technology, Gliwice, Poland
}

\begin{abstract}
The study aims to investigate possible alternative paths of reusing Cement Kiln Dust in mining technologies or as mineral sorbent for $\mathrm{CO}_{2}$ capture. Properties of $\mathrm{CKD}$ and bottom slag slurry were assessed and these were ia.: chemical composition, compressive strength and excess water content. Results show that $\mathrm{CKD} /$ bottom slag slurry mixed in the proportion of $25 \% / 75 \%$ can be used as a backfill material if concentration of contaminants in the leaching tests is at the acceptable level. Second part of the study was devoted to the assessment of $\mathrm{CKD}$ as a sorbent in Calcium looping technologies or for mineral carbonation. TGA and DSC study shows that the rate of $\mathrm{CO}_{2}$ capture (carbonation) is determined by the free $\mathrm{CaO}$ content. The highest carbonation rate was within the temperature range of $600-800^{\circ} \mathrm{C}$.
\end{abstract}

\section{Introduction}

Cement industry generates various waste both in the form of solids (dust) as well as gases $\left(\mathrm{CO}_{2}\right)$. This industry accounts for over $5 \%$ of global $\mathrm{CO}_{2}$ emissions [1]. One of the by-products of cement manufacturing is the Cement Kiln Dust (CKD). CKD is created in the kiln during the production of cement clinker. The dust is a particulate mixture of partially calcined and unreacted raw feed, clinker dust and ash, enriched with alkali sulfates, halides and other volatiles. Particle size distribution is irregular as in case of fly ash. Particulates of CKD are captured by the exhaust gases and collected in dust control devices such as cyclones, baghouses and electrostatic precipitators. Each $\mathrm{Mg}$ of manufactured cement creates $41 \mathrm{~kg}$ of CKD [2]. Taking into consideration global production of cement which was approximately 4200 million $\mathrm{Mg}$ of cement in 2016 [3] the CKD accounts for a considerably large share of generated solid waste. Therefore, there is a need to utilize CKD in order to reduce its impact on the environment. In general, CKD consists primarily of calcium carbonate and silicon dioxide which is similar to the cement kiln raw feed, but the amount of alkalies, chloride and sulfate is usually considerably higher in the dust.

High content of calcium oxide is of particular importance when considering CKD as a mineral binder of $\mathrm{CO}_{2}$. In most of the cases the CKD is reversed back into the kiln however there is still a considerably large amount which is either deposited or beneficially used.

Common uses of CKD include soil stabilization, waste stabilization or solidification, filling of voids in mine reclamation operations, etc. Summary of technologies where CKD can be used is shown in Table 1. The problem with CKD is its variation in chemical composition which depends on the type of operation, dust collection method, type of fuel used and other factors. Nevertheless, in this study an attempt is made to assess the possibility of using
CKD in mine reclamation purpose or void filling and to assess the potential of $\mathrm{CO}_{2}$ mineral carbonation of CKD. This is particularly important given the fact the high energy intensity of cement industry and as a consequence - $\mathrm{CO}_{2}$ emissions. Recovering of waste such as CKD in underground mine technologies (backfilling, void filling) helps to reduce the environmental impact both as a result of removing fine particulate from the atmosphere but also by reducing the impact of mining (surface subsidence reduction). The same refers to mineral carbonation where gaseous waste $\left(\mathrm{CO}_{2}\right)$ is combined with a solid waste, in this case CKD, forming non- reactive solid which can be also used for backfilling [4].

Table 1. Beneficial uses of Cement Kiln Dust (CKD) [5, 6].

\begin{tabular}{|c|c|}
\hline Current uses & Potential uses \\
\hline Soil stabilization & $\begin{array}{c}\text { Permeable Reactive } \\
\text { Barrier filling }\end{array}$ \\
\hline $\begin{array}{c}\text { Waste } \\
\text { stabilization/solidification }\end{array}$ & Heavy metal adsorption \\
\hline Cement additive / blending & Fertilizer production \\
\hline Landfill liner & $\mathrm{CO}_{2}$ mineral carbonation \\
\hline Wastewater neutralization & \\
\hline Road foundation & \\
\hline Concrete products & \\
\hline Mine reclamation & \\
\hline
\end{tabular}

Since CKD contains high content of unreacted $\mathrm{CaO}$ under high temperature the $\mathrm{CaO}$ should react with $\mathrm{CO}_{2}$ in carbonation-calcination thermochemical reaction:

$$
\mathrm{CaO}(g)+\mathrm{CO}_{2}(g)=\mathrm{CaCO}_{3}(\mathrm{~s})
$$

This reaction has been thoroughly studied mostly for the $\mathrm{CO}_{2}$ capture processes $[7,8]$ and in the calcium looping systems $(\mathrm{CaL})[9]$.

\footnotetext{
* Corresponding author: marcin.lutynski@polsl.pl
} 


\section{Materials and methods}

In this study a sample of Cement Kiln Dust from one of the cement plants from the East of Poland which is representative for a typical cement manufacturing process in Poland was selected.

Two separate analysis were carried out, first the CKD was assessed in terms of its suitability in reusing it as a backfill material for underground void filling. For this case CKD has to be mixed with other silicate material which increases the strength of a mixture. CKD acts as an activator and a $\mathrm{CaO}$ supplier. For this purpose a bottom slag (or sand from fluidized bed) was chosen. Fluidized bed sands are a waste in accordance with the European Union waste catalogue with a code no. 100124.

Chemical composition of bottom slag and CKD used in the study is shown in Fig. 2.

Table 2. Chemical composition of CKD and bottom slag.

\begin{tabular}{|c|c|c|}
\hline Constituents & CKD & $\begin{array}{c}\text { Bottom slag } \\
\mathbf{1 0} \text { 01 24 }\end{array}$ \\
\hline & $(\% \mathrm{~m} / \mathrm{m})$ & $(\% \mathrm{~m} / \mathrm{m})$ \\
\hline $\mathrm{SiO}_{2}$ & 13.7 & 52.4 \\
\hline $\mathrm{Al}_{2} \mathrm{O}_{3}$ & 3.4 & 18.5 \\
\hline $\mathrm{Fe}_{2} \mathrm{O}_{3}$ & 1.1 & 5.9 \\
\hline $\mathrm{CaO}$ & 48.7 & 11.2 \\
(including free) $\mathrm{CaO}$ & 14.3 & 4.2 \\
\hline $\mathrm{MgO}$ & 0.4 & 0.9 \\
\hline $\mathrm{Na}_{2} \mathrm{O}$ & 2.5 & 0.7 \\
\hline $\mathrm{K}_{2} \mathrm{O}$ & 16.0 & 1.6 \\
\hline $\mathrm{SO}$ & 8.6 & 4.9 \\
\hline $\mathrm{TiO}_{2}$ & 0.1 & 0.8 \\
\hline $\mathrm{P}_{2} \mathrm{O}_{5}$ & 0.2 & 0.1 \\
\hline $\mathrm{SrO}$ & 0.1 & 1.1 \\
\hline $\mathrm{ZnO}$ & 0.1 & 0.2 \\
\hline $\mathrm{Chloride}$ & 0.4 & 0.01 \\
\hline Ignition losses & 6.3 & 3.7 \\
\hline
\end{tabular}

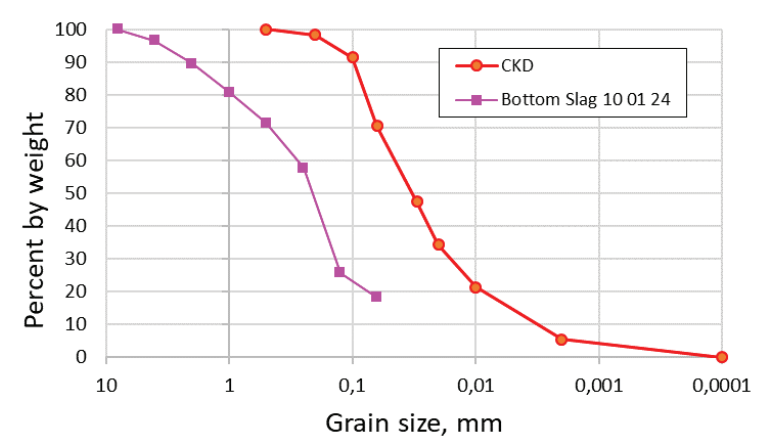

Fig. 1. Particle size analysis of materials used in the study.

Since the mixture of CKD and bottom slag is to be used for the purpose of backfilling the content of trace metal elements has to be analyzed. In Fig. 3 metal trace elements content both for the CKD and bottom slag is shown.

Particle size distribution of both materials is shown in Fig. 1. Particle size analysis of CKD were carried out with light scattering particle size analyser Micromeritics
Saturn DigiSizer II Mo. 5205, for the bottom slag the analysis were done with the use of a conventional sieve analysis.

Table 3. Metal trace elements content in CKD and bottom slag.

\begin{tabular}{|c|c|c|}
\hline Element & CKD & $\begin{array}{c}\text { Bottom } \\
\text { slag } \\
\mathbf{1 0 ~ 0 1 ~ 2 4}\end{array}$ \\
\hline & $(\mathrm{ppm})$ & $(\mathrm{ppm})$ \\
\hline $\mathrm{Ag}$ & $<2$ & $<2$ \\
\hline $\mathrm{As}$ & $<2$ & $<2$ \\
\hline $\mathrm{Ba}$ & 97 & 284 \\
\hline $\mathrm{Cd}$ & 241 & $<2$ \\
\hline $\mathrm{Cr}$ & 14 & 73 \\
\hline $\mathrm{Cu}$ & 186 & 521 \\
\hline $\mathrm{Mo}$ & $<2$ & 5 \\
\hline $\mathrm{Mn}$ & 85 & 287 \\
\hline $\mathrm{Ni}$ & 16 & 29 \\
\hline $\mathrm{Pb}$ & 2174 & 98 \\
\hline $\mathrm{Rb}$ & 1042 & 87 \\
\hline $\mathrm{Sb}$ & 44 & $<2$ \\
\hline $\mathrm{Sr}$ & 829 & 256 \\
\hline $\mathrm{V}$ & 9 & 117 \\
\hline $\mathrm{Zn}$ & 1423 & 203 \\
\hline
\end{tabular}

Particle size distribution curve shows that the particle size distribution in CKD is similar to that of a raw cement. This was also observed by Wang et al. [10]. Particle size analysis show that the distribution is irregular and is comprised mostly of sizes $0,0001-0,1$. The uneven distribution of grains and low sphericity of grains as proven by Ahmari and Zhang [11] (see Fig. 2) causes high water demand when preparing the slurry.

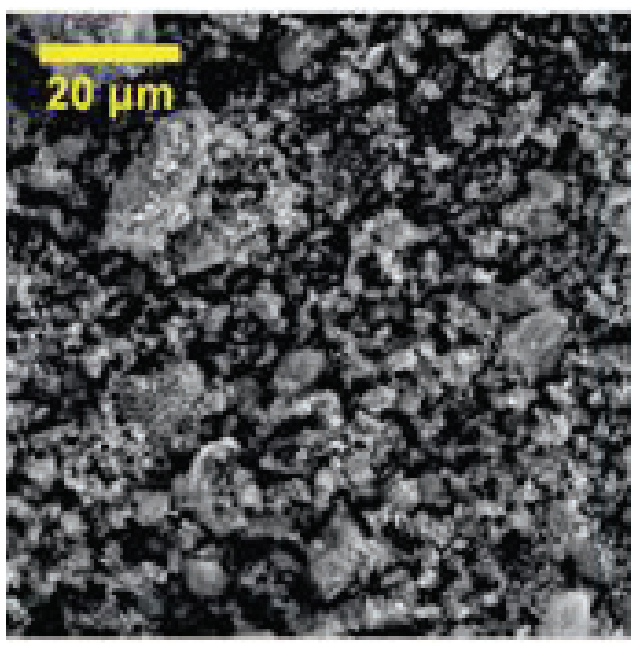

Fig. 2. SEM image of Cement Kiln Dust [11].

CKD and bottom slag were mixed in the proportion $25 \% / 75 \%$ and tested in accordance with the polish standard PN-G-11011:1998 "Materials for selfsolidifying backfill and gob grouting. Materials and testing". The following properties were tested:

- Spread of a slurry - selection of W/S ratio

- Excess water 
- Compressive strength

- Soaking resistance

Other properties such as compressibility, permeability and curing time were not included in the tests since these parameters are determined for a specific application. The compressive strength tests were conducted in accordance with the standard PN-EN 196 1:2006. „Methods of testing cement - Part 1: Determination of strength". Compressive strength was tested on prismatic test specimens 40x40x160 mm in size. Example specimen is shown in Fig. 3. For comparison same test was carried out for bottom slag without the addition of CKD. The W/S ratio of a slurry was chosen to match the spread of $180 \mathrm{~mm}$. The spread of $180 \mathrm{~mm}$ of a slurry provides proper hydraulic transportability with minimum excess water [12]. Specimens were cured for 28 days in a climatic chamber in order to simulate in-situ conditions of a mine i.e. $90 \%$ humidity and temperature of $22^{\circ}$.

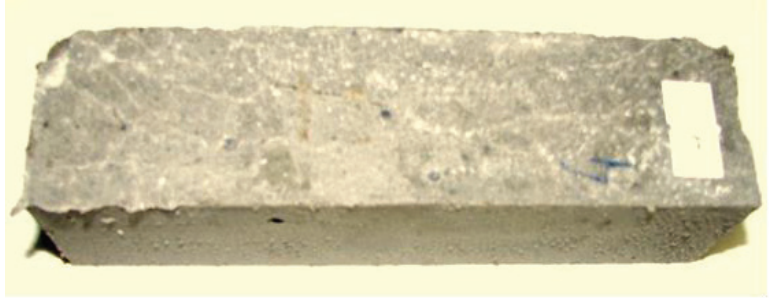

Fig. 3. Specimen prepared for a compressive strength test of CKD and bottom slag mixture after 28 days of curing in climatic chamber.

The $\mathrm{CO}_{2}$ mineral carbonation potential was assessed with the use of thermal analyzer NETZSCH 449 F3 Jupiter. Approximately $20 \mathrm{~g}$ of sample was used for the tests. The heating rate during the experiment was $10^{\circ} \mathrm{C} / \mathrm{min}$ up to the temperature of $1100^{\circ} \mathrm{C}$ with consecutive cooling phase down to $40^{\circ} \mathrm{C}$ with the same rate. During the heating phase a $\mathrm{CO}_{2}$ flow of $25 \mathrm{ml} / \mathrm{min}$ was applied whereas during the cooling stage - an inert gas $\left(\mathrm{N}_{2}\right)$ was flowing with the same rate as $\mathrm{CO}_{2}$. Two analytical methods were used ie. Differential Scanning Calorimetry and Thermogravimetry which allowed to record changes in the weight of the sample.

\section{Results}

\subsection{Backfill material}

Results of the test of CKD/bottom slag slurry for the purpose of backfilling are shown in Table 4.

Compressive strength of CKD/bottom slag slurry after 28 days of curing is $4,7 \mathrm{MPa}$ and is much above the minimum requirement for self-solidifying backfill which is $0,5 \mathrm{MPa}$ (according to the PN-G-11011:1998 standard). The soaking resistance $(12,4 \%)$ is also below the threshold which is specified in the same standard as $20 \%$. The excess water observed after the curing was also considerably low $(0,6 \%)$ and is much below the standard value for self-solidifying backfill (7\%) as well as for gobgrouting $(15 \%)$. The water to solid ratio corresponds to the spread of the slurry which in accordance with the standard for both self-solidyfing backfill and gobgrouting should be above $90 \mathrm{~mm}$. Since metal trace elements were measured for solid materials (see Tab. 4) in order to transpose these results into real conditions, i.e. after solidifying, there is a need to conduct a leaching test. Therefore, it was decided to conduct an additional leaching test of solidified sample in accordance with the same standard. Result of the leaching test is shown in Table 5.

Table 4. Results of tests of CKD/bottom slag slurry for the purpose of backfilling.

\begin{tabular}{|c|c|}
\hline Water/solid ratio (-) & 0.32 \\
\hline Spread (mm) & 175 \\
\hline Excess water (\%) & 0.6 \\
\hline $\begin{array}{c}\text { Compressive strength } \\
\text { after 28 days (MPa) }\end{array}$ & $\begin{array}{c}4.7(2.1 \text { for bottom } \\
\text { slag) }\end{array}$ \\
\hline Soaking resistance (\%) & 12.4 \\
\hline
\end{tabular}

Leaching test shows that the majority of leached out elements (contaminants) is below the threshold for the wastewaters introduced into the soil. The only parameter above the threshold is Potassium (max. $80 \mathrm{mg} / \mathrm{dm}^{3}$ ) and Lead (max. 0,5 mg/dm ${ }^{3}$ ) [13]. High contents of $\mathrm{Pb}$ and $\mathrm{K}_{2} \mathrm{O}$ are observed in CKD rather than bottom slag which implies that other slurry proportion eg. 10\% CKD and $90 \%$ of bottom slag would probably dilute and immobilize sufficiently these elements. Since CKD acts as an activator and increases overall strength of the $m$ ixture the mechanical strength is much above the minimum value of $0,5 \mathrm{MPa}$ and most probably will be enough with the addition of $90 \%$ of bottom slag. This indicates that $\mathrm{CKD} /$ bottom slag slurries could be successfully used as the self-solidifying backfill and/or as a gob-grout. This would be a safe and efficient method of reusing this waste.

Table 5. Results of CKD/bottom slag slurry leaching test.

\begin{tabular}{|c|c|}
\hline Parameter & Value \\
\hline $\mathrm{Cd}\left(\mathrm{mg} / \mathrm{dm}^{3}\right)$ & $<0.005$ \\
\hline $\mathrm{Cr}\left(\mathrm{mg} / \mathrm{dm}^{3}\right)$ & $<0.02$ \\
\hline $\mathrm{Zn}\left(\mathrm{mg} / \mathrm{dm}^{3}\right)$ & 0.08 \\
\hline $\mathrm{Mg}\left(\mathrm{mg} / \mathrm{dm}^{3}\right)$ & $<0.5$ \\
\hline $\mathrm{Mn}\left(\mathrm{mg} / \mathrm{dm}^{3}\right)$ & $<0.02$ \\
\hline $\mathrm{Cu}\left(\mathrm{mg} / \mathrm{dm}^{3}\right)$ & $<0.02$ \\
\hline $\mathrm{Ni}\left(\mathrm{mg} / \mathrm{dm}^{3}\right)$ & $<0.02$ \\
\hline $\mathrm{Pb}\left(\mathrm{mg} / \mathrm{dm}^{3}\right)$ & 0.66 \\
\hline $\mathrm{K}\left(\mathrm{mg} / \mathrm{dm}^{3}\right)$ & 1380 \\
\hline $\mathrm{Na}\left(\mathrm{mg} / \mathrm{dm}^{3}\right)$ & 143 \\
\hline $\mathrm{Sr}\left(\mathrm{mg} / \mathrm{dm}^{3}\right)$ & 1.9 \\
\hline $\mathrm{Ca}\left(\mathrm{mg} / \mathrm{dm}^{3}\right)$ & 204 \\
\hline $\mathrm{Fe}\left(\mathrm{mg} / \mathrm{dm}^{3}\right)$ & 0.5 \\
\hline $\begin{array}{l}\mathrm{Chlorides} \\
\left(\mathrm{mg} / \mathrm{dm}^{3}\right)\end{array}$ & 20 \\
\hline $\begin{array}{l}\mathrm{Sulphates} \\
\left(\mathrm{mg} / \mathrm{dm}^{3}\right)\end{array}$ & 215 \\
\hline $\mathrm{pH}$ & 12 \\
\hline
\end{tabular}




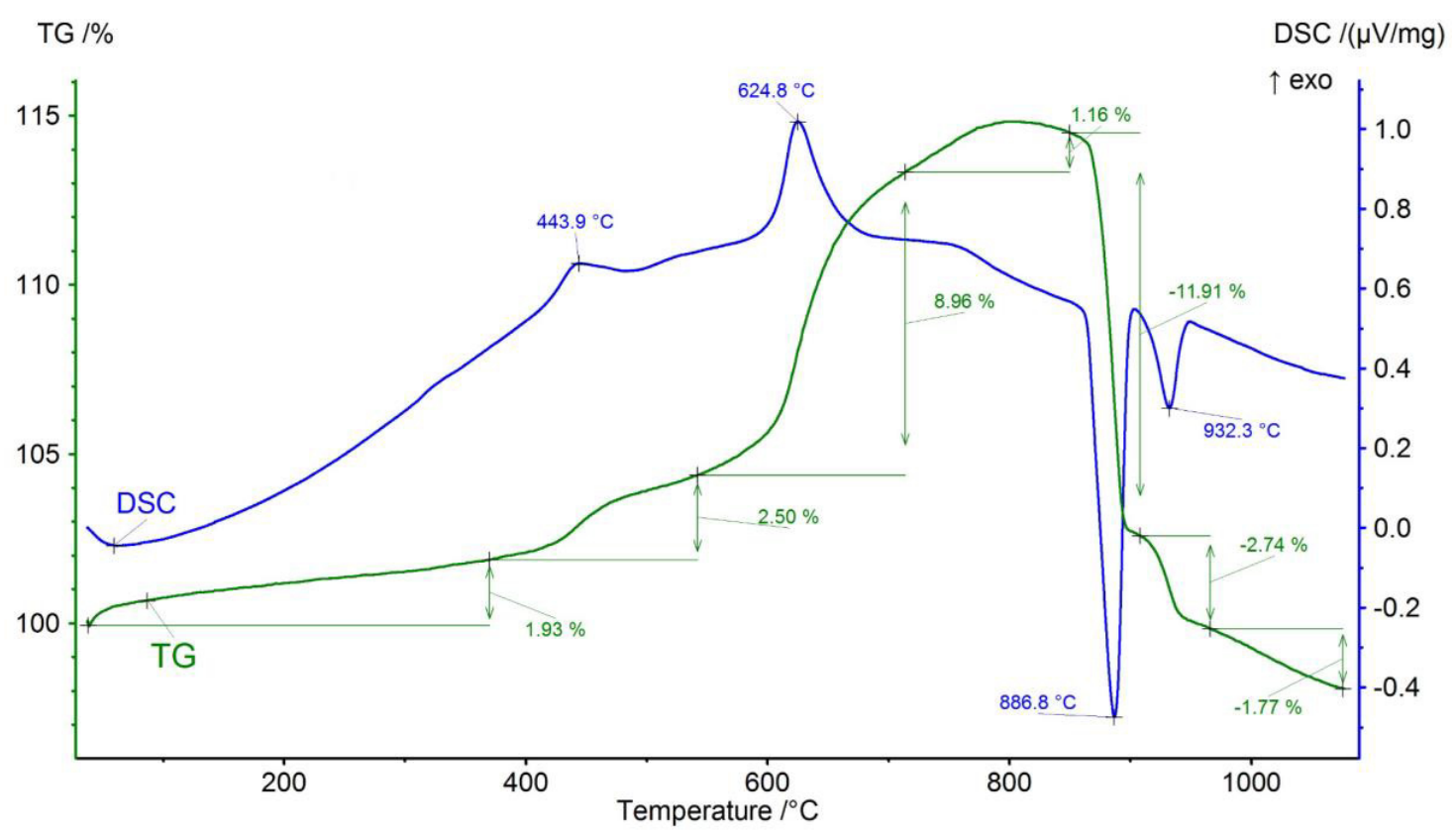

Fig. 4. TGA and DSC analysis of CKD sample.

\section{$3.2 \mathrm{CO}_{2}$ mineral carbonation}

Thermogravimetric and DSC analysis results are shown in Fig. 4. As it was mentioned, the maximum temperature of the experiment was $1100^{\circ} \mathrm{C}$ and it was sufficient to see the decomposition of carbonates. The TGA curve increases by $1,93 \%$ up to the temperature of approximately $480^{\circ} \mathrm{C}$ which probably indicates physical sorption of $\mathrm{CO}_{2}$ on CKD particles (slight increase in DSC curve). The second and third stage of mass growth up to the temperature of approximately $850^{\circ} \mathrm{C}$ indicates carbonation with two maxima at $443,9^{\circ} \mathrm{C}$ and $624,8^{\circ} \mathrm{C}$. Above $800^{\circ} \mathrm{C}$ a rapid two stage decomposition of calcium carbonate (calcination) is observed with two maxima at the temperature of $886,8^{\circ} \mathrm{C}$ and $932,3^{\circ} \mathrm{C}$. The total mass uptake by the sorbent is $14,55 \%$ which corresponds to the free $\mathrm{CaO}$ content in the CKD (see Tab. 2). This indicates that $\mathrm{CKD}$ could be potentially used for carbon looping technologies or as a mineral sorbent where $\mathrm{CO}_{2}$ forms $\mathrm{CaCO}_{3}$ from free $\mathrm{CaO}$ making the $\mathrm{CKD}$ less reactive and inert to the environment. Temperature of carbonation and calcination observed in the experiment are similar to those in other studies on limestone or fly ash [14-16]. Further tests need to be conducted in order to obtain more information on the regeneration of the sorbent or its properties after carbonation.

\section{Conclusions}

In this study and attempt was made to show alternative paths of Cement Kiln Dust reuse in mining technologies (as a backfill) and as a mineral adsorbent of $\mathrm{CO}_{2}$ in capture technologies. The following conclusions can be drawn:
- $\mathrm{CKD}$ has a relatively high content of $\mathrm{CaO}$ which acts as an activator when mixed with silicate materials increasing their compressive strength,

- CKD/bottom slag slurry can be used as a backfill or gob grouting material in underground mining if the chemical leaching test results are positive. Both compressive strength and excess water content allow to use the tested slurry as a backfill material. The concentration of contaminants in the leachate is at the acceptable level except $\mathrm{Pb}$ and $\mathrm{K}$.

- The rate of $\mathrm{CO}_{2}$ capture (carbonation) is determined by the free $\mathrm{CaO}$ content. The highest carbonation rate is within the temperature range of $600-800^{\circ} \mathrm{C}$.

- Additional studies are necessary to observe the regeneration rate of the sorbent and decrease in the carbonation capacity

\section{References}

1 E. Worrell, L. Price, N. Martin, C. Hendriks, L.O. Meida, Annu. Rev. Energy Environ. 26, 303-329 (2001)

2 A.H. Sulaymon, A.A. Faisal, Q.M. Khaliefa, J. Hazard. Mater. 297, 160-172 (2015)

3 www.statista.com

4 P. Buryan, P. Donat, S. Buryan, Inż. Miner. 16 (2015)

5 W.S. Adaska, D.H. Taubert, others, in:, Cem. Ind. Tech. Conf. Rec. 2008 IEEE, IEEE, 210-228 (2008)

6 M.-J. Kim, S.Y. Pak, D. Kim, S. Jung, KSCE J. Civ. Eng. 21, 629-635 (2017) 
7 J.C. Abanades, E.J. Anthony, J. Wang, J.E. Oakey, Environ. Sci. Technol. 39, 2861-2866 (2005)

8 V. Nikulshina, C. Gebald, A. Steinfeld, Chem. Eng. J. 146, 244-248 (2009)

9 A. Perejón, L.M. Romeo, Y. Lara, P. Lisbona, A. Martínez, J.M. Valverde, Appl. Energy 162, 787807 (2016)

10 K. Wang, A. Mishulovich, S.P. Shah, J. Mater. Civ. Eng. 19, 112-119 (2007)

11 S. Ahmari, L. Zhang, Constr. Build. Mater. 40, 1002-1011 (2013)

12 P. Mazurkiewicz, Z. Piotrowski, A. Tajduś, Lokowanie Odpadów w Kopalniach Podziemnych, (Kraków, 1997)
13 Regulation of the Minister of Environment of 24 July 2006 on Conditions to $\mathrm{Be}$ Met for the Introduction of Sewage into the Water or Soil, and on Substances Particularly Harmful to the Aquatic Environment (Journal of Laws No 137, Item 984, as Amended)

14 V. Nikulshina, C. Gebald, A. Steinfeld, Chem. Eng. J. 146, 244-248 (2009)

15 D.N. Huntzinger, J.S. Gierke, L.L. Sutter, S.K. Kawatra, T.C. Eisele, J. Hazard. Mater. 168, 31-37 (2009)

16 M. Erans, V. Manovic, E.J. Anthony, Appl. Energy 180, 722-742 (2016) 